\title{
An Empirical Analysis of Entrepreneurship Development Program on Potential Entrepreneurs
}

\author{
Sarita Solanki Rana, ${ }^{1, *}$ Bhupender Som ${ }^{2}$, S. K. Jain ${ }^{3}$, Rajbir Singh ${ }^{4}$ \\ ${ }^{1}$ Maharaja Surajmal Institute of Technology, New Delhi, India \\ ${ }^{2}$ Jagan Institute of Management Studies, Rohini, Delhi India \\ ${ }^{3}$ Department of Management Studies, Indian Institute of Technology, Delhi, India \\ ${ }^{4}$ Deenbandhu Chhotu Ram University of Science and Technology, Haryana, India
}

Copyright $\bigcirc 2018$ by authors, all rights reserved. Authors agree that this article remains permanently open access under the terms of the Creative Commons Attribution License 4.0 International License

\begin{abstract}
Entrepreneurship is the most fascinating component of modern day economy. Lots of training programs related to entrepreneurship emerged due to this. This paper is an attempt to determine the impact of entrepreneurship orientation on potential entrepreneurs. In particular, the study takes into account the perceived benefits before and after the particular program and maps the gap between perceived benefits and actual delivery. A sample of 311 respondents (participants) is collected for the study. The participants were engage in an Entrepreneurship Development Program run by Indian Institute of Technology, New Delhi (India). The paper discusses parameters around which Entrepreneurship Development Program is knitted. A structure schedule is prepared and data is collected on a five point scale in the beginning and at the end of the program. Collected data is fed to SPSS and gap between perceived and actual delivery is identified along with significance. Motivation to start a venture is also observed through structured approach. Necessary descriptive and inferential statistical tools are applied as and when needed. Results are presented trough necessary graphs and tables.
\end{abstract}

Keywords Entrepreneur, Entrepreneur Orientation, Leadership, Training

\section{Introduction and Literature Review}

Fortune 500 companies have lost more than 5 million jobs, but more than 34 million new jobs have been created. Entrepreneurial activity increased from 2008 rates for both men and women (from 0.42 percent to 0.43 percent for men and from 0.24 percent to 0.25 percent for women). The Nice Côte d'Azur 2011 Entrepreneurship Barometer report finds the appetite for more targeted entrepreneurship education and training - most striking. This appetite is particularly strong in rapid-growth markets, where $80 \%$ of entrepreneurs think that students need to follow specific training to become entrepreneurs (compared with an average of $70 \%$ across the G20 nations). Revenues from Entrepreneurship Education Programs reached INR7.9 billion in 2010 and are estimated to grow at a CAGR of $13.7 \%$ to INR10.7 billion by 201226-Entrepreneurship Education in India: Trend and Factors Assessment Survey', Research and Markets, 2011

The entrepreneurial revolt has taken hold across the globe and has incontestably impacted the world of business forever. Entrepreneurship has emerged over the last two decades as arguably the most potent economic force the world has ever witnessed. With that expansion has come a similar increase in the field of entrepreneurship education. The recent growth and development in the curriculum and programs devoted to entrepreneurship and new-venture creation have been noteworthy. Entrepreneurship was considered to be an employment generation sector and recognized as an instrument for tapping latent talent and harness it. The government envisaged a promotion package and financial assistance in the form of fund and non-fund to facilitate the setting up of new units or the expansion of existing line of activities. The package consisted of incentives, subsidies, concessions, infrastructural facilities, technical and managerial guidance, etc., through a network of organizations for supporting entrepreneurship development.

The overall purpose of entrepreneurship education is to attain motives by application of knowledge and skills. Typical attitudes related to entrepreneurship include autonomy, initiative, pro-activeness, and responsibility, while skills include creative problem solving, perseverance, and response to challenges.

Entrepreneurship orientation programs display proactive and innovative actions and create entrepreneurial environment opportunities. Some of the dimensions of Entrepreneurship Oriented Programs are 
building confidence, pro-activeness and risk taking qualities. These dimensions are useful for potential entrepreneurs for their significant growth and business performance. EOPs help potential entrepreneur to act in a strategic orientated either in its processes, methods or decision styles which indirectly help him to attain his expected benefits. EOPs help potential entrepreneur understand about entrepreneurial initiatives and provide link between their intentions and attitude.

Karimi, S., Biemans et.al (2012, May), have assessed the impact of entrepreneurship education oriented programs on entrepreneurial intentions of participant's next entrepreneurship courses at six Iranian universities. Results concluded that entrepreneurship oriented programs significantly influence perceived behavioral outcome in term of entrepreneurship field. However, no support was found for the effects of entrepreneurship oriented programs on attitudes toward entrepreneurship and intention. Rachel Shinnar et. al.(2009) investigated student and faculty attitudes toward entrepreneurship and entrepreneurship education programs. The authors examined students' level of interest in entrepreneurial education, perceptions of motivations and barriers to startup businesses, and occupational aspirations. Student and faculty respondents represented a variety of disciplines in and outside colleges of business. Key findings stated that interest among non-business students suggests a significant opportunity to formally expand entrepreneurship-related education beyond the business school. M. Edwin Gnanadhas (2008) has evaluated the performance of Entrepreneurial Development Programmes from the stance of the banks, to study the factors influencing the attitude of the entrepreneurs towards the Entrepreneurship Development Programmes. The result stated that there is no relationship between the age group of the prospective entrepreneurs and their attitude towards the training program. Also there no relationship was found between the educational background and the level of attitude and it is proved that educational background does not influence the attitude of the respondents towards the training program. It was also concluded that the family background of the respondents influences the attitude of the respondents towards the training program.

Kristiansen, S., \& Indarti, N. (2004) have stated that individuals who perceive the existence of business opportunities and other benefits (e.g., access to capital, availability of business information) are more likely to make the decision to start a new business. On the other hand, if the individuals have negative perception regarding the environment of the business, they may not decide to start their own business

Autio, E., Keeley, R.H., Klofsten, M., Parker, G. and Hay, M. (2001). have empirically applied theory of planned behviour to students' entrepreneurial intentions and assessed the impacts of entrepreneurship education oriented programs on the perceived behavioral and found no support for the effects of the entrepreneurship education oriented programs on attitudes toward entrepreneurship and entrepreneurial intention. A possible explanation for this conclusion was also provided, that the students had a positive attitudes towards entrepreneurship and high entrepreneurial intention at the beginning of the program and therefore there was less scope for changing their attitudes and intention. Kolvereid, L. (1996) has emphasized that in addition to personality traits, several individual difference variables have also been found to predict entrepreneurial behaviors. This paper have analyzed that those with prior experience in entrepreneurial activities, like business background have higher entrepreneurial intention compared to those with no prior experience.

\section{Objectives and Scope of the Study}

- To identify the gap between expected and actual delivery.

- To check the significance between expected and actual delivery.

- To identify the level of motivation for entrepreneurship.

The study can prove to be useful for institutions operating in field of entrepreneurship training and development programs. Since all necessary demographics are recorded therefore study can be used to cater the particular need with respect to demographics.

\section{Research Methodology}

An exploratory and descriptive research design is followed to carry the research. Secondary literature is used to carry exploratory research and necessary parameters around which an Entrepreneurship Development Program revolves are identified. The parameters are organized in a structured scheduled questionnaire and responses are recorded on a five point scale for further analysis.

All respondents were participants in and Entrepreneurship Development Program at Indian Institute of Technology New Delhi hence a convenient sample is collected due to limited time and resources.

Information through schedule technique is used to collect the data to avoid problem of low response, language barrier and partial information. Suitable coding of data is generated in spreadsheet so that it can be used in MS Excel and SPSS conveniently. After formulation of hypothesis suitable hypothesis testing statistical tools are used to test them.

The results are presented descriptively and inferentially. Contemporary and relevant charts and graphs are used for the purpose of descriptive statistics and suitable statistical 
methods are applied for inference.

Related to objectives following alternative hypothesis are formulated;

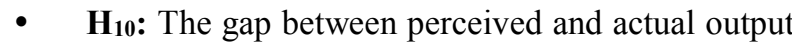
of EDP is significant.

- H12: EDP doesn't motivate participants for Entrepreneurship.

\section{Data Analysis and Interpretation}

Depending on the need of study the respondents are divided under certain demographics. These demographics are age, sex, education, and family background. The careful selection of demographics is made on the basis of physiological variation in perceiving Entrepreneurship development programmes. As age play an important role in perceiving any training program, with increase in variable of age the thought process becomes mature and the overall perception changes accordingly. Likewise gender plays an important role in perceiving anything. It is a proven fact that variation in perception is significant with respect to gender. Education plays an important role in perceiving training programs of such kind. As education increases, the expectation from a training program becomes narrow or specific. Family background is another important aspect in perceiving EDP. An entrepreneur coming from a business family background will expect advanced discussions in EDP while a first generation entrepreneur coming from a service family will expect clarity on basic business aspects from EDP. An appropriate distribution of demographics is maintained while picking respondents for the study. Following table shows the distribution of sample on demographics.

Table 1. Demographic Distribution of Sample

\begin{tabular}{|c|c|}
\hline \multicolumn{2}{|c|}{ Gender } \\
\hline Male & 237 \\
\hline Female & 74 \\
\hline \multicolumn{2}{|c|}{ Education } \\
\hline Under Graduate \\
\hline Graduate & 114 \\
\hline PG & 60 \\
\hline \multicolumn{2}{|c|}{ Age } \\
\hline $20-30$ & 137 \\
\hline $30-40$ & 171 \\
\hline $40-50$ & 84 \\
\hline 50 and $>$ & 28 \\
\hline & 28 \\
\hline & 311 \\
\hline
\end{tabular}

Source: filed survey
Though the data is collected with other parameters, scope of this paper is limited to the demographics of age and education,

In order to understand expectation of attendees from Entrepreneurship Development Programmes, respondents were asked about the perceived importance of the program on eleven parameters. The formulated question, "By participating in an Entrepreneurship development program, I shall be skilled with",

i. Business opportunity identification

ii. Market research

iii. Knowledge -sources of finance

iv. Confidence Building

v. Management skills

vi. Process of starting venture

vii. Risk taking

viii. Project Report Preparation and B plan

ix. Network building

Above mentioned parameters are measured by two questions. First respondents' expected importance for specific parameters is measured on a five point scale of importance mentioned below:

\begin{tabular}{|c|c|c|c|c|}
\hline $\begin{array}{c}\text { Least } \\
\text { Important }\end{array}$ & $\begin{array}{c}\text { Not } \\
\text { Important }\end{array}$ & Important & $\begin{array}{c}\text { Moderately } \\
\text { Important }\end{array}$ & $\begin{array}{c}\text { Most } \\
\text { Important }\end{array}$ \\
\hline 1 & 2 & 3 & 4 & 5 \\
\hline
\end{tabular}

After quantification the data is coded in spreadsheet. The workbook so produced served as a platform for MS Excel and SPSS. Two software are used for analyzing the data as and when needed. Analysis of variance, t-test, and $\chi^{2}$ tests are used for analysis rigorously. While comparison of means along with variance is also used as and when needed.

As the respondents select EDP program with some expectations. Often EDP's do not deliver as per expectations. Hence it became very important to analyze gap between expectation and delivery. Therefore, subsequently analyzing importance of expectations we collected responses on same parameters after completion of entrepreneurship development program. A five point scale for meeting the expectations is used to quantify the gap for all ten parameters in following manner.

\begin{tabular}{|c|c|c|c|c|}
\hline $\begin{array}{c}\text { Didn't meet } \\
\text { expectations } \\
\text { at all }\end{array}$ & $\begin{array}{c}\text { Didn't meet } \\
\text { expectations }\end{array}$ & $\begin{array}{c}\text { Met } \\
\text { expectations }\end{array}$ & $\begin{array}{c}\text { Moderately } \\
\text { met } \\
\text { expectations }\end{array}$ & $\begin{array}{c}\text { Higher } \\
\text { than } \\
\text { expected }\end{array}$ \\
\hline 1 & 2 & 3 & 4 & 5 \\
\hline
\end{tabular}

Section 1: This section studies Objective 1 and 2

First the radar plot is constructed to understand the sample output with respect to expected and actual output. Following diagram is presented by rescaling the mean values so that difference between expected and actual output can be observed easily. 


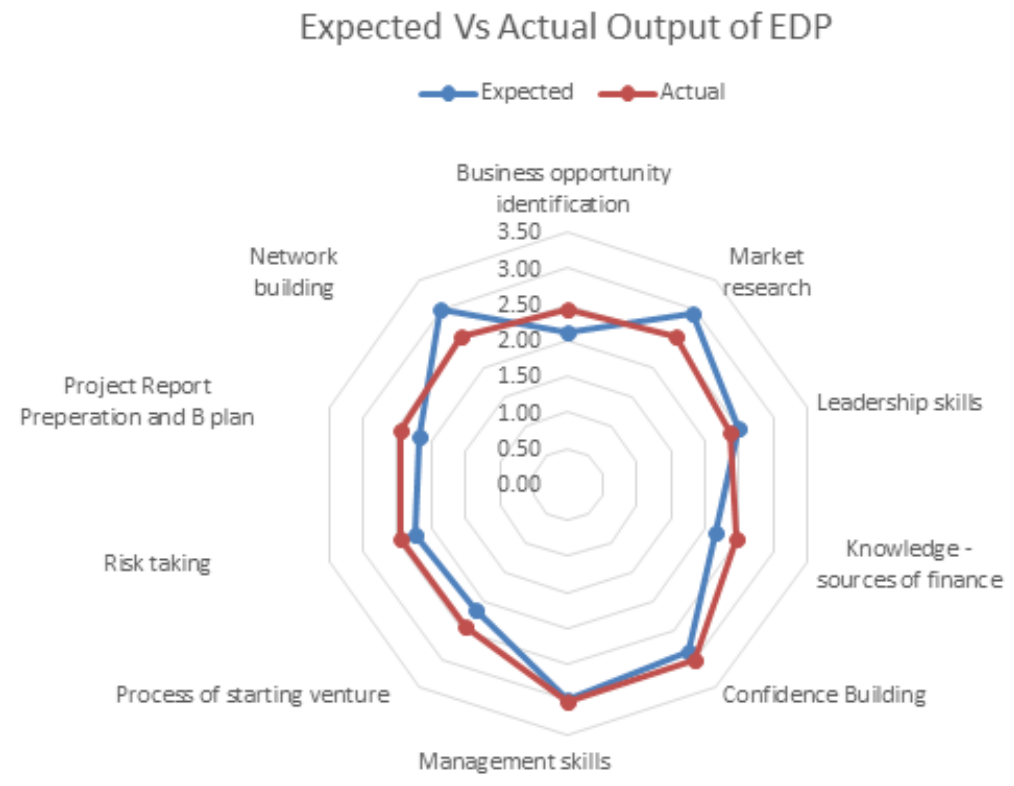

Figure 1. Expected Vs Actual Output of EDP

It can be observed from figure -1, that there is a huge gap between expected and actual output for marketing research enhancement and network building. This shows that people were expecting a higher output in terms of network building and market research skill enhancement but the delivery from EDP does not remain up to the mark. The delivery for enhancement of leadership skills is also little less than expected. Hence, sample output suggests that for EDP network building and market research are the areas of major concern where the delivery is less than expectation while leadership skill enhancement shall also be focused upon.

Now to generalize these results and to check whether the mismatch of expectations and delivery is just a matter of chance or statistically significant enough to believe that these areas should be worked upon we formulate and test following hypothesis by using t-test as the population standard deviation is not known.

$\boldsymbol{H}_{101}$ : The difference between expected and actual delivery of network building is significant

Table 2. t-Test: Paired Two Sample for Means

\begin{tabular}{ccc}
\hline Statistics & $\begin{array}{c}\text { Network } \\
\text { Building (A) }\end{array}$ & $\begin{array}{c}\text { Network } \\
\text { Building (E) }\end{array}$ \\
\hline Mean & 2.5273 & 3.0064 \\
Variance & 1.4178 & 1.6709 \\
Observations & 311 & 311 \\
Pearson Correlation & 0.580 & \\
Hypothesized Mean & 0 & \\
Difference & 310 & \\
df & -7.40464 & \\
t Stat & $6.25 \mathrm{E}-13$ & \\
$\mathrm{P}(\mathrm{T}<=\mathrm{t})$ one-tail & 1.649784 & \\
$\mathrm{t}$ Critical one-tail & $1.25 \mathrm{E}-12$ & \\
$\mathrm{P}(\mathrm{T}<=\mathrm{t})$ two-tail & 1.967646 & \\
$\mathrm{t} \mathrm{Critical} \mathrm{two-tail}$ & & \\
\end{tabular}

From table -2 , it is clear that statistically the difference between expected output from network building and actual output of network building is not significant. Hence, we do not reject null hypothesis in this case as t-stat falls within the region of acceptance on t-curve. That indicates that the difference between actual and expected output of network building is by random chance. Yet the improvements can be made for network building as people find the actual output below expectation.

$\boldsymbol{H}_{102}$ : The difference between expected and actual delivery of Market Research is significant

Table 3. t-Test: Paired Two Sample for Means

\begin{tabular}{ccc}
\hline Statistics & $\begin{array}{c}\text { Market } \\
\text { research (A) }\end{array}$ & $\begin{array}{c}\text { Market } \\
\text { research (E) }\end{array}$ \\
\hline Mean & 2.527331 & 2.92926 \\
Variance & 1.391993 & 1.769173 \\
Observations & 311 & 311 \\
Pearson Correlation & 0.656966 & \\
Hypothesized Mean Difference & 0 & \\
Df & 310 & \\
t Stat & -6.76063 & \\
$\mathrm{P}(\mathrm{T}<=\mathrm{t})$ one-tail & $3.41 \mathrm{E}-11$ & \\
$\mathrm{t}$ Critical one-tail & 1.649784 & \\
$\mathrm{P}(\mathrm{T}<=\mathrm{t})$ two-tail & $6.83 \mathrm{E}-11$ & \\
$\mathrm{t}$ Critical two-tail & 1.967646 & \\
\hline
\end{tabular}

From table -3 , it is clear that statistically the difference between expected output from market research and actual output of market research is not significant. We can observe that $\mathrm{t}$-stat falls in the region of acceptance as it is between two tailed critical limits of \pm 1.96 . Therefore, we do not reject null hypothesis in this case. That shows that 
the difference between actual and expected output of market research is a matter of chance. Still the improvements can be made for market research parameter as people find the actual output below expectation.

$\boldsymbol{H}_{103}$ : The difference between expected and actual delivery of leadership skills is significant

Table 4. t-Test: Paired Two Sample for Means

\begin{tabular}{ccc}
\hline Statistics & $\begin{array}{c}\text { Leadership } \\
\text { skills(A) }\end{array}$ & $\begin{array}{c}\text { Leadership } \\
\text { skills (E) }\end{array}$ \\
\hline Mean & 2.37299 & 2.482315 \\
Variance & 1.118494 & 0.940815 \\
Observations & 311 & 311 \\
Pearson Correlation & 0.758017 & \\
Hypothesized Mean & 0 & \\
Difference & 310 & \\
$\mathrm{df}$ & -2.71534 & \\
$\mathrm{t}$ Stat & 0.003496 & \\
$\mathrm{P}(\mathrm{T}<=\mathrm{t})$ one-tail & 1.649784 & \\
$\mathrm{t}$ Critical one-tail & 0.006992 & \\
$\mathrm{P}(\mathrm{T}<=\mathrm{t})$ two-tail & 1.967646 & \\
$\mathrm{t}$ Critical two-tail &
\end{tabular}

From table -4 , it can be observed that statistically the difference between expected output from leadership skills and actual output of market leadership skills is not significant. it can be observed that $t$-stat falls in the region of acceptance as it is between two tailed critical limits of \pm 1.96. Therefore, we do not reject null hypothesis in this case as well. That shows that the difference between actual and expected output of leadership skills is a matter of chance. Still the improvements can be made for leadership skill parameter as people find the actual output below expectation.

We can observe that the difference between actual and expected delivery during an EDP is not statistically significant. Though there is a gap between three areas i.e. market research, leadership skills and network building.

Section 2: This section analyses the third objective of the study.

The objective was to identify whether Entrepreneurship development program results in mobilizing attendees to start new ventures. Respondents are first asked whether they were running entrepreneurship venture before joining EDP or not, following pie chart shows the results.

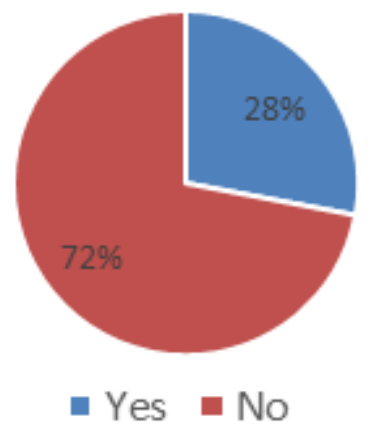

Figure 2. Were you operating a new set up venture when you began EDP
The figure above shows that $72 \%$ of the people were not running any venture before joining the entrepreneurship development program. Therefore, either first generation entrepreneurs or people who want to set up their own business are seeking guidance from such programs. Only $28 \%$ people joined the program who were already entrepreneurs. Some of them may have started their venture in unorganized way, hence they come to learn the systematic way to run the venture. These $28 \%$ respondents may also include people who come to seek the knowledge from EDP so that they can take their business from local to global.

In all 224 people out of 311 were not running any venture. It became essential part of the study to understand how many out of these 224 non-entrepreneur participants started their own venture after attending EDP.

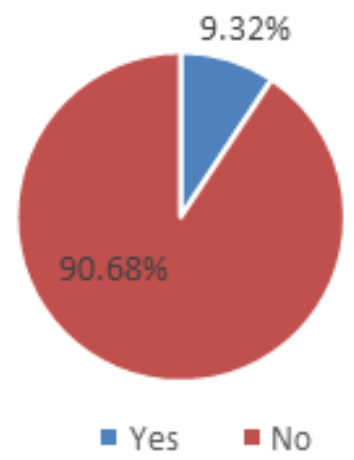

Figure 2. Venture Set-up After attending EDP

To surprise only $9 \%$ people started their own venture after attending EDP. The scope of research may be short time span of recording this response after finishing of EDP. The number may increase after certain amount of time. Only 26 out of 224 respondents mobilized and started their ownn business.

A hypothetical figure of $20 \%$ (the figure is gathered by brainstorming and rigorous discussion with experts) is set for measuring the success of program i.e. if minimum $20 \%$ people start their ventures after attending EDP the program can be considered as a successful one. We apply t-test, to identify whether results can be generalized or not for population. Whether the program is considered a successful one or not. We formulate following alternate hypothesis

$H_{-} \alpha$ : EDP was not successful $(\mathrm{P}<.20)$

Table -5. t-test for testing of proportion

\begin{tabular}{|c|c|}
\hline Sample Statistics & \\
\hline Number of successes(x) & 26 \\
\hline Sample Size(n) & 224 \\
\hline Sample proportion(p) & 0.1161 \\
\hline Standard Error (S.E.) & 0.0214 \\
\hline p-value & 0.01 \\
\hline$\alpha$ & 0.05 \\
\hline
\end{tabular}


Since $\mathrm{p}$-value is less than $\alpha=0.05$ hence we reject null hypothesis that EDP was a success in this case. We can statistically say that results hold good for population. Only $1.3 \%$ of people starting their venture are really a less number. Hence the program must be aimed for more conversion.

\section{Conclusions}

In this paper primary data is used for understanding (i) the gap between actual and expected output from an EDP program (ii) the motivation to become entrepreneur. We identified that the gap exists among three key areas of entrepreneurship development program, these key areas are;

- Marketing research

- $\quad$ Network building

- Leadership skills

Though the gap between actual and expected is not statistically significant but still we recommend that an EDP shall focus more on the mentioned areas. Further it is observed that EDP's are not serving a great purpose when it comes to start a new venture. Only $9 \%$ participants started their venture after such program and this proportion is significantly low.

The results of paper can be of immense use for EDP organizers as it gives bird's eye view on areas of improvement.

\section{REFERENCES}

[1] "Karimi, S., Biemans, H., Lans, T., Mulder, M., Chizari, M (2012, May). The Role of Entrepreneurship Education in Developing Students' Entrepreneurial Intentions. Proceedings of WICaNeM 2012, The 10th Wageningen International Conference on Chain and Network Science, Wageningen University, Wageningen, The Netherlands, p. 22.

[2] Autio, E., Keeley, R.H., Klofsten, M., Parker, G. and Hay, M. (2001). Entrepreneurial intent among students in Scandinavia and in the USA. Enterprise and Innovation Management Studies, 2 (2): 145-60.

[3] Kolvereid, L. (1996b). Predictions of employment status choice intentions, Entrepreneurship Theory and Practice, 21 (1): 47-57.

[4] Kristiansen, S., \& Indarti, N. (2004). Entrepreneurial intention among Indonesian and Norwegian students. Journal of Enterprising Culture, 12(1), 55-78.

[5] Entrepreneurship Education: Attitudes Across Campus, Rachel Shinnar et. al.(2009), Journal of Education for Business, Heldref Publications

[6] M. Edwin Gnanadhas (2008), Entrepreneurial development programmes conducted by public sector banks in TamilNadu-Success or failure, Journal of Services Research, 